\title{
Twenty Years of Common Agricultural Policy in Europe: A Bibliometric Analysis
}

\author{
Giulio Fusco
}

check for

updates

Citation: Fusco, G. Twenty Years of Common Agricultural Policy in Europe: A Bibliometric Analysis. Sustainability 2021, 13, 10650. https://doi.org/10.3390/su131910650

Academic Editor: Prashant Kaushik

Received: 6 September 2021

Accepted: 22 September 2021

Published: 25 September 2021

Publisher's Note: MDPI stays neutral with regard to jurisdictional claims in published maps and institutional affiliations.

Copyright: (C) 2021 by the author. Licensee MDPI, Basel, Switzerland. This article is an open access article distributed under the terms and conditions of the Creative Commons Attribution (CC BY) license (https:// creativecommons.org/licenses/by/ $4.0 /)$.
Istituto Pugliese di Ricerche Economiche e Sociali, 70122 Bari, Italy; giulio.fusco@ipres.it

\begin{abstract}
The last few years have been marked by the increasing attention paid by policymakers to agricultural policies. Within this scenario, the Common Agricultural Policy represents one of the main initiatives developed by the European Commission to enhance the agricultural sector. Academics have actively contributed to the debate through empirical studies in order to evaluate the main strengths and weakness related to the public investments made by the European Commission. However, despite the relevance of the topic, the scientific debate is characterized by a high degree of fragmentation caused by the involvement of academics with different scientific backgrounds. Building on this evidence, this paper aims to contribute to the scientific debate on Common Agricultural Policy through a bibliometric analysis. The findings reveal the existence of three independent and complementary research clusters.
\end{abstract}

Keywords: common agricultural policy; political economy; agricultural economics; bibliometrics

\section{Introduction}

The agricultural sector covers a central role within society. In particular, the agricultural sector can support the achievement of ambitious goals such as the mitigation of risks related to biodiversity losses and food security [1]. Furthermore, the agricultural sector impacts many environmental issues, such as climate change, cycles of nitrogen and phosphorus, water contamination, and soil degradation. Thus, it could represent an enabler of the mitigation of the risks related to the lack of controls and monitoring by governments [2,3].

The Eurozone is characterized by a high degree of attention paid by regulators and policymakers to the agricultural sector. Introduced in 1957, the Common Agricultural Policies (CAPs) have shaped the European Union's agricultural sector [4] by supporting different practices that mitigate wide-scale biodiversity loss [4] and by the mitigation of the negative externalities related to climate change, soil erosion, and land degradation. In 2019, the European Commission invested more than EUR 58 billion in the sustainable agricultural sector through different initiatives, such as market measures (EUR 2.37 billion), rural development (EUR 14.18 billion) and income support (EUR 41.43 billion) [5]. However, many criticisms have been made by policymakers regarding its effectiveness. In this sense, taking into consideration these limitations, the CAP has changed its skin several times, modifying its tools and objectives [6].

The new CAPs (post-2020) proposed in June 2018 underlined the need to give more attention to environmental and sustainability issues. In particular, the new CAPs introduced a New Green Architecture and a delivery model that offers Member States the possibility of greater flexibility to implement the CAPs. With this new formulation, the new CAPs have a series of new objectives directed towards policy integration and multi-disciplinary research to achieve food system sustainability targets. In fact, with a series of nine specific objectives, this new reform is seeking to improve the environmental, social, territorial, and health aspects connected to agriculture sustainability, and not only the productive and economic aspects of the precedent reforms [7]. 
In the last decades of the 20th century, research interest in the political reform of the agricultural sector has increased. However, the scientific debate on CAPs is highly fragmented due to the coexistence of different perspectives. Indeed, the purpose of this study is to systemize the scientific knowledge about CAPs, and to try to identify future research lines to give support to researchers, policymakers, and entrepreneurs. Building on prior bibliometric studies [8,9], this paper aims to identify the main contributions provided by academics to the debate about CAPs through a multidimensional approach based on the integration of different indicators such as co-citation, citation analysis, and co-occurrences [10].

The rest of the study is structured as follows. First, the methodology is discussed, describing the methods and databases. Then follows the principal results obtained in both the descriptive and bibliometric analyses, in addition to a discussion of the same. Finally, in the conclusions section, limitations and a subsection on suggested future research are provided.

\section{Methodology}

In the last few years, many academics have underlined the need to support the interactions between academics, practitioners, and policymakers. Sharma and Bansal [11] argued that literature reviews should support this process via the ability to focus the analysis on specific topics with direct managerial implications. Furthermore, literature reviews can be relevant for the comprehension of the managerial implications of agricultural policies [12-14].

In the methods of literature reviews, bibliometrics are a methodological approach widely used to collect quantitative insights regarding emerging or consolidated topics [10]. Contrarily to traditional literature reviews, bibliometric studies consist of a quantitative approach based on the conjoined analysis of multiple indicators such as co-citation, citation, and bibliographic coupling [8,15]. In this sense, they provide insights regarding the field and its theoretical roots.

Building on preliminary evidence, the analysis was built with Bibliometrix, a software widely used to conduct bibliometric analysis [16]. Bibliometrics is an open source tool based on R, a statistical software used by academics and data scientists for data analysis and visualization. In this sense, bibliometric analyses are also supported by graphical representations, which useful to the evaluation made by researchers [17]. Furthermore, the analysis was integrated through the adoption of VosViewer, a software widely adopted by academics to conduct bibliometric research [15].

The research protocol used to conduct the research consists of (a) data collection, (b) descriptive analysis and (c) bibliometric analysis. The data were retrieved from Scopus, one of the main databases used by academics to conduct bibliometric analyses. Despite the coexistence of many scientific databases, the analysis was conducted on Scopus in order to consider only theoretical contributions characterized by an adequate degree of scientific soundness. The use of the Scopus database avoids potential bias and/or omissions related to the analysis of a limited set of journals [18]. In addition, we have checked the consistency of our sample with cross-checks via WoS.

To evaluate the scientific debate around the CAPs, we used the following criteria:

1. Keywords-“Common Agricultural Policy";

2. Language-_English";

3. Source type-Scientific Journal.

The analysis considered only papers published in the English language. The choice to consider only papers published in journals instead of books, book chapters, and conference proceedings is related to the central role played by journals in the current scenario. In this sense, the methodological approach used avoids the risks related to the duplication of research.

The period considered in the analysis was between 2001 and 2020. Papers published in 2021 were not considered due to the revision of the CAPs in 2021-2027, while the choice 
to consider 2001 as the starting point was related to the opportunity to evaluate the large time span of 20 years.

As regards the specific bibliometric methods used to evaluate the field, the analysis was built with multiple indicators focused on three different perspectives: a) authors, b) sources, and c) documents. Despite the interlinkages between the three dimensions, their analyses provide different insights. Furthermore, for each perspective, we have considered different indicators in order to understand the past, the present, and the future of the scientific debate on CAPs $[19,20]$.

The final sample consists of 1824 documents published in 544 sources. The most prolific year was 2019 , and the average increase over the period is $11.91 \%$. In this sense, the field could be considered relevant for academics, as evidenced by the increasing number of studies published over the years.

\section{Results}

A bibliometric approach provides detailed information and insight regarding the evolution of scientific fields or topics. To give a full perspective of the evolutionary pathways that have characterized the field and identify the most influential studies, topics, and sources, we used a comparative approach to bibliometrics that compares and integrates the results from different indicators, as previously described in the methodology section. The results are presented with three different perspectives according to the unit of analysis under investigation: authors, journals, and documents; in addition, we provide the identification of conceptual themes and keywords.

\subsection{Authors Analysis}

Regarding the analysis at the authors level, the findings show three different steps of analysis; the first level shows the most relevant authors (Figure 1), secondly, the most locally cited (Figure 2), and thirdly, results about the authors' country's scientific production (Figure 3).
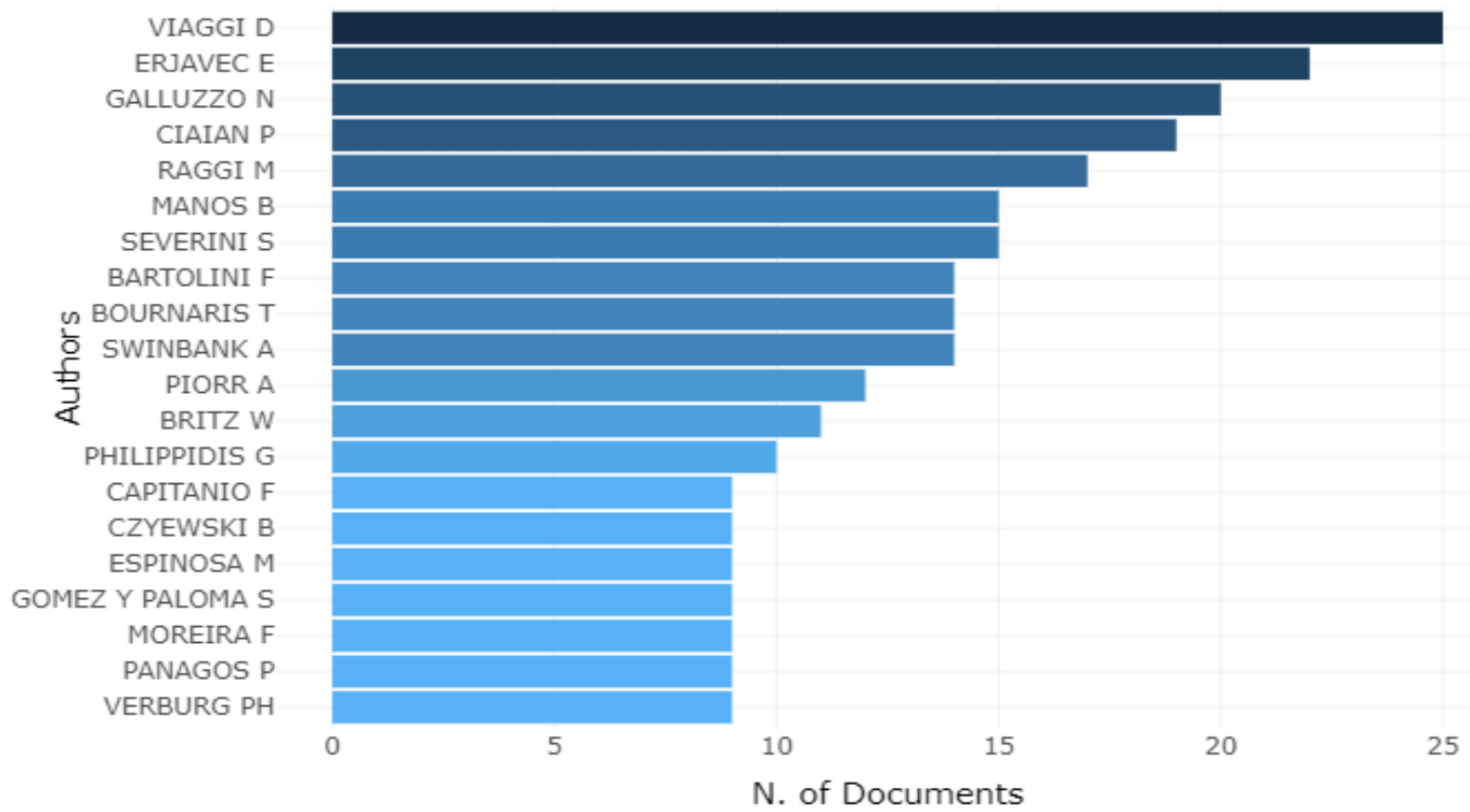

Figure 1. Most relevant authors. 


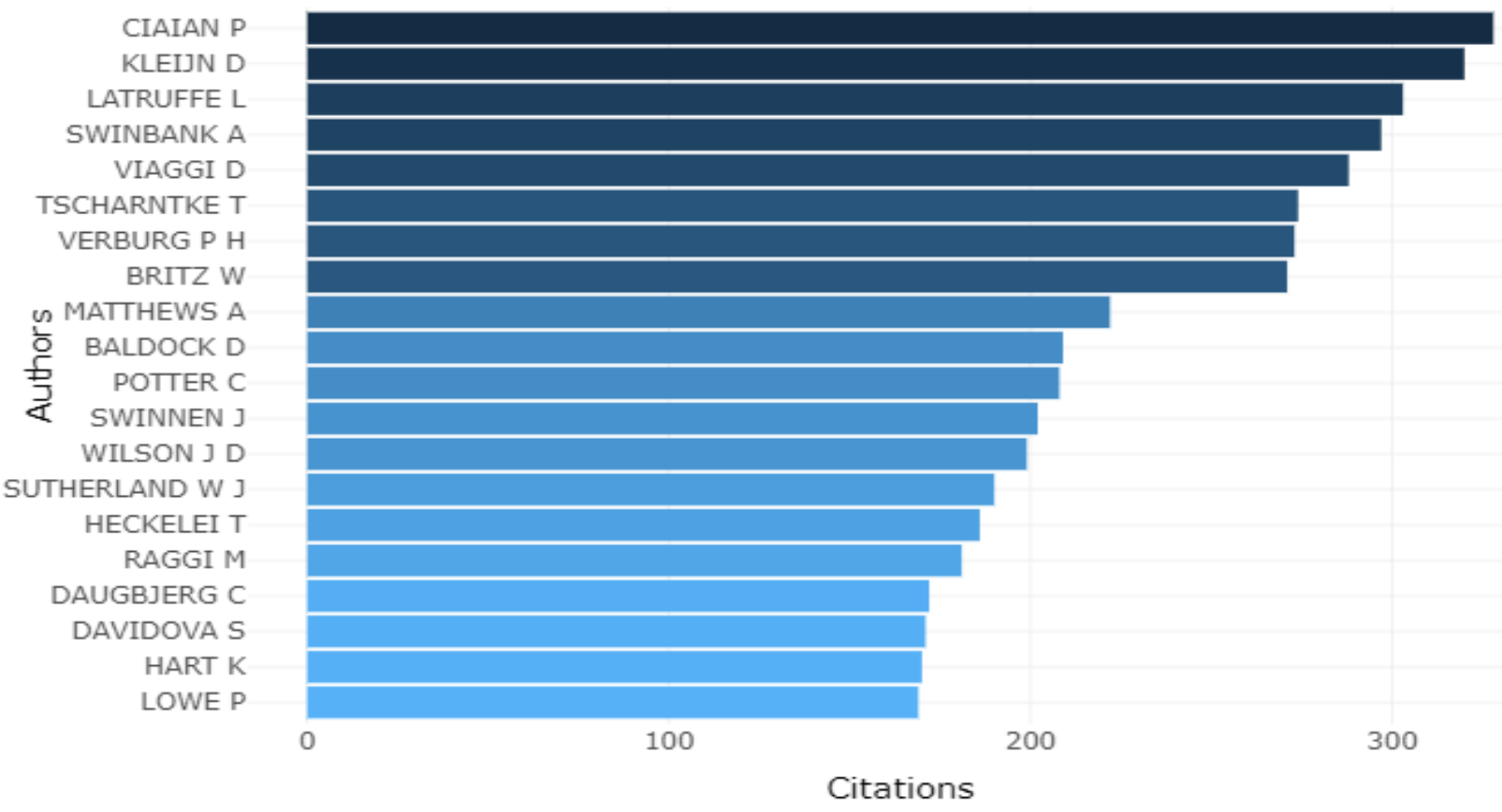

Figure 2. Most locally cited authors.

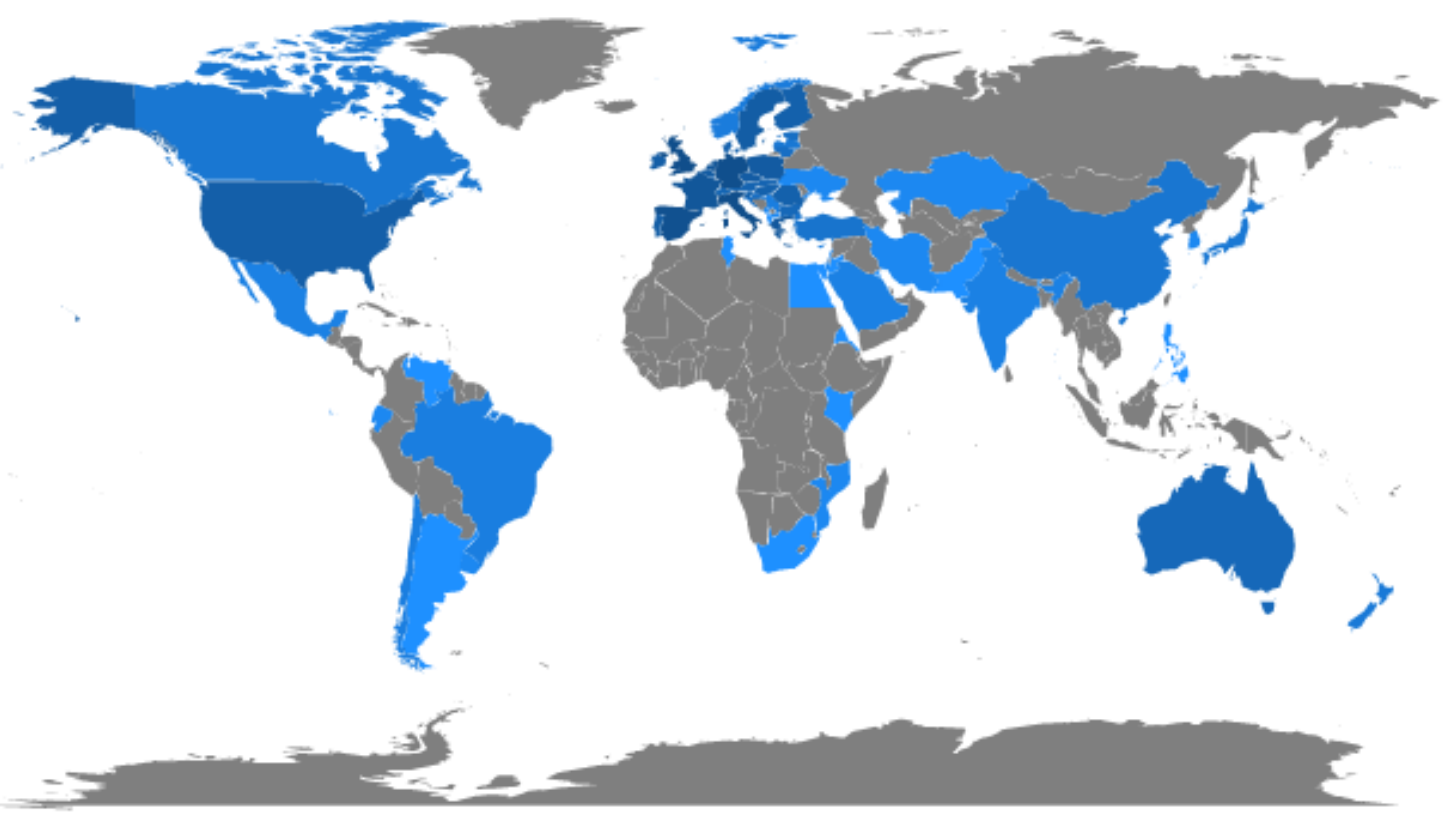

Figure 3. Country scientific production.

The findings underline that in recent years, many researchers have investigated the CAPs and their effects. This attention has led to the realization of a substantial stream of research. The dataset included 4127 authors of 1824 publications. It is interesting to note that, according to the relevance of the agricultural sector in the Italian context, most of the authors with a high number of publications are Italians (Figure 1), such as Viaggi, Galluzzo, Raggi, Severini Bartolini, and Capitanio. The other authors with the highest numbers of articles about CAPs come from the UK, Greece and Europe. It is interesting to note the scientific contribution of Galluzzo, because, during the period considered in the analyses, he wrote 20 articles under a single name.

In addition, the analysis reveals that the authors with the highest numbers of citations are different from those presented in Figure 1, where we found primarily Italian's authors. 
In Figure 2, we see that the authors with a number of citations of more than 300 are Cian (328), Kleijn (320) and La Truffe (303).

Figure 3 represents the most important research outputs in this first step of the analysis; it represents the country's scientific production and provides us very important information about the geographical distribution of the research output. The majority of the scientific outputs were developed in Europe, in particular, the UK (492), Italy (486), and Germany (442). Outside the European context, most studies were published in the USA (around 90), confirming the importance of the agricultural sector in the USA, and their knowledge about public policy in this sector.

\subsection{Source Analysis}

The second step of the analysis is focused on the analysis of the journals that have dealt with the CAPs. The analysis of the journal is very important because it allows us to provide a picture of the outlets that have most contributed to the development of Common Agricultural Policy from 2001, with three different perspectives. In this section, we analyze the journal in which has been published the highest number of articles on agricultural policy (most prolific journals), the journal with the highest number of citations (to show which havs the high scientific impact on the scientific community in this field; most cited journal), and finally, we investigate the annual trend in the number of articles in the most important journal to determine the evolution of scientific research.

The dataset used for the analysis is composed of publications from 544 journals; from the analysis of the most prolific journal, it is possible to identify which are the main topics treated as part of Common Agricultural Policy, and which are the future developments. These include financial support, farmer's income, rural development, sustainability, food security and management of natural resources [21-25]. The journals with the highest numbers of articles are Land Use and Policy (139), Eurochoices (69), Journal of Agricultural Economics (41), and Sustainability (40).

In addition, Table 1 provides some information about the most cited journals. The average number of citations per journal was 19.44. The greatest numbers of citations were from Land Use Policy (1301), American Journal of Agricultural Economics (705), Journal of Agriculture Economics (607), Agriculture (576), and Agriculture Ecosystem and Environment (572), each with more than 500 citations. These journals appear to be the most impactful journals after 2001 on this topic. Is important to underline that, except for the first position occupied by the Land Use and Policy journal, there are variations in the rankings of mostcited journals and most prolific journals, pointed out that there is no correspondence between publication and impact on the scientific community. 
Table 1. Most cited journals.

\begin{tabular}{cc}
\hline Sources & Articles \\
\hline LAND USE POLICY & 1301 \\
AMERICAN JOURNAL OF AGRICULTURAL & 705 \\
ECONOMICS & 607 \\
JOURNAL OF AGRICULTURAL ECONOMICS & 576 \\
AGRICULTURE & 572 \\
AGRIC ECOSYST ENVIRON & 494 \\
EUROPEAN REVIEW OF AGRICULTURAL & 483 \\
ECONOMICS & 409 \\
JOURNAL OF RURAL STUDIES & 392 \\
SCIENCE & 387 \\
JOURNAL OF APPLIED ECOLOGY & 340 \\
FOOD POLICY & 339 \\
J RURAL STUD & 332 \\
AGRICULTURAL ECONOMICS & 321 \\
SOCIOLOGIA RURALIS & 320 \\
ECOL ECON & 319 \\
J APPL ECOL & 289 \\
AGRIC SYST & 285 \\
NATURE & 280 \\
BIOLOGICAL CONSERVATION & 280 \\
ECOLOGICALECONOMICS & \\
JOURNAL OF ENVIRONMENTAL & \\
\hline &
\end{tabular}

Figure 4 investigates the trend between articles published and journals. It is possible to affirm that, from this point of view, the principal journals are consolidated with a positive trend over the period considered (2001-2020). It is important to underline the trend shown by the Sustainability journal, which registers exponential growth in this field; it is the journal that has contributed the most to the development of this research field in the last year. In this second step of the analysis, it is found that the scientific investigation of agricultural policy, sustainability and rural development is mostly published in sectorial journals.

\subsection{Documents' Analysis}

In recent years (in particular from 2019), the evolution of the field in terms of the volume of scientific production has shown exponential growth in the number of articles investigating agricultural policy (Figure 5). The year 2019 registered an increase of over $11 \%$, demonstrating that this is a relevant topic for academics. This exponential growth is linked with the necessity to investigate the effects of PAC 2014-2020, and to determine the scientific soundness for the implementation of the new PAC 2021-2017 [26-28]. 


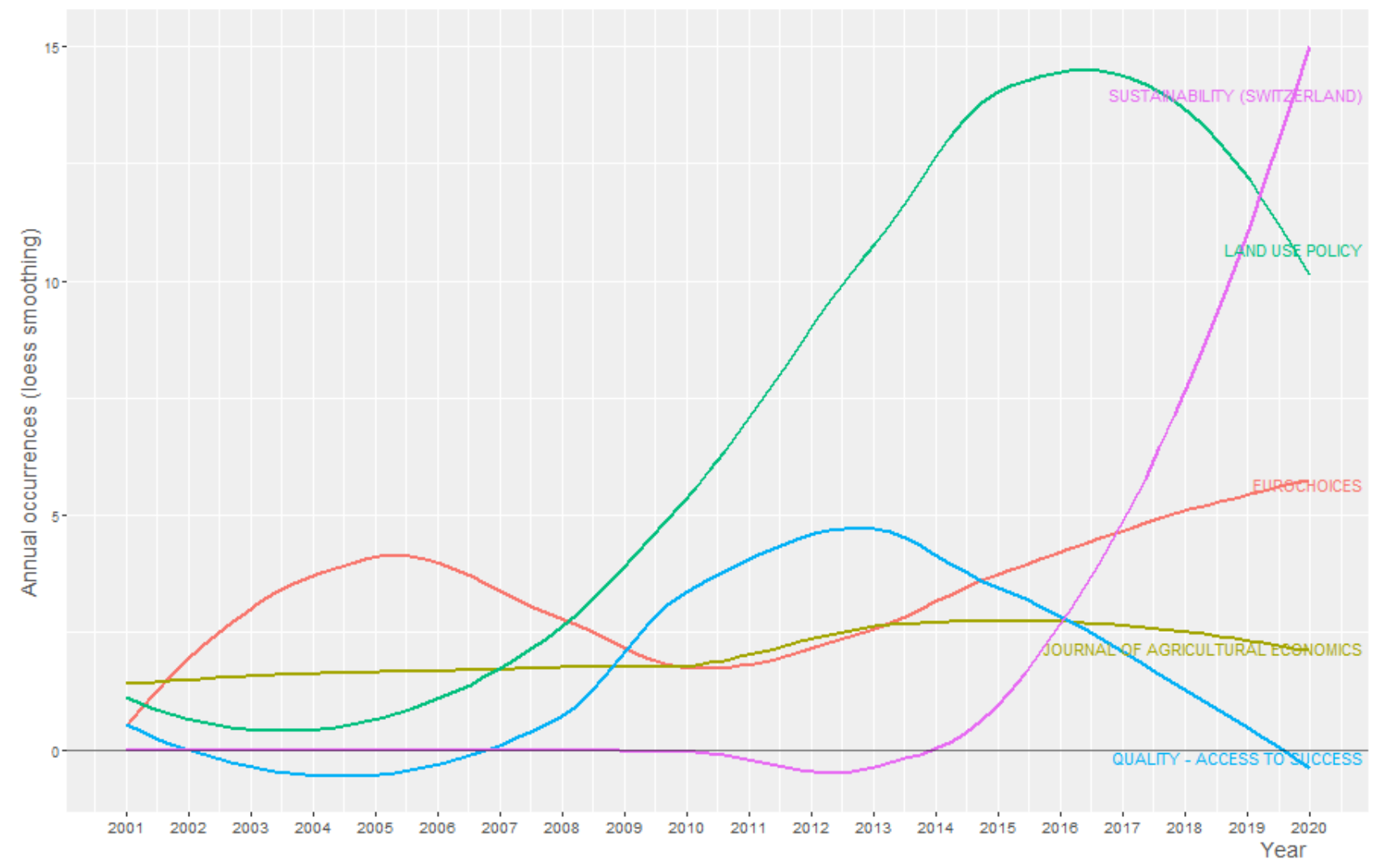

Figure 4. Annual trend in the number of articles in the most important journals.

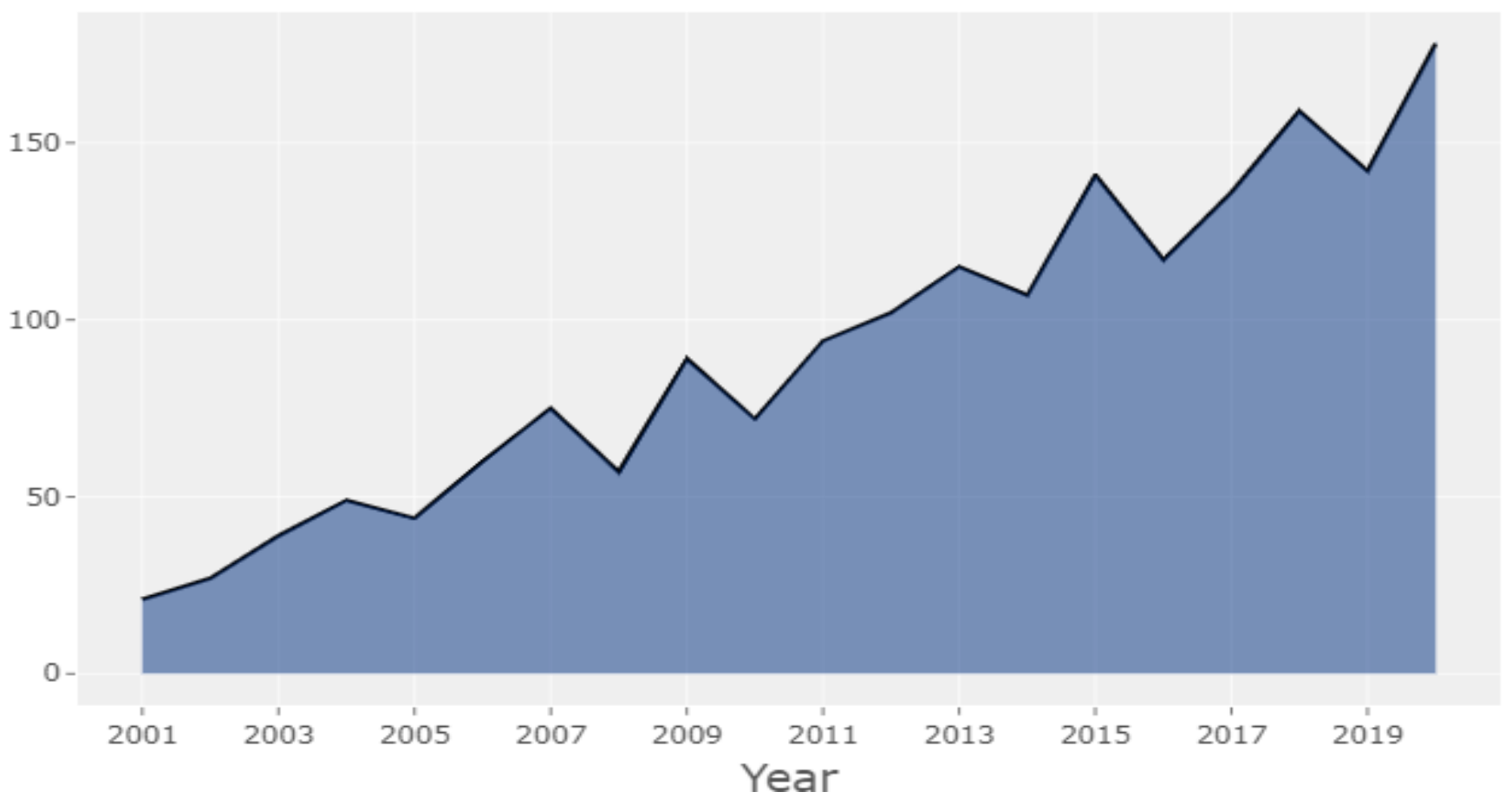

Figure 5. Article per years.

The analysis of the references cited is developed in two stages. In Table 2, we show the paper with the highest number of citations and the average citations per year, to give a 
substantial measure of the impact of this paper in the research community, while Table 3 provides a different citation analysis. In this table, we list the articles in the dataset (via co-citation analysis) that were cited by the others articles in the sample, providing a picture of the contributions of the main references that have influenced the development of the field in recent years.

Table 2. Most cited papers in the sample.

\begin{tabular}{|c|c|c|c|}
\hline Paper & DOI & Total Citations & TC Per Year \\
\hline OLESEN JE, 2002, EUR J AGRON & 10.1016/S1161-0301(02)00004-7 & 863 & 43.15 \\
\hline $\begin{array}{c}\text { STOATE C, 2001, J ENVIRON } \\
\text { MANAGE }\end{array}$ & 10.1006/jema.2001.0473 & 818 & 38.9524 \\
\hline $\begin{array}{c}\text { STOATE C, 2009, J ENVIRON } \\
\text { MANAGE }\end{array}$ & 10.1016/j.jenvman.2009.07.005 & 761 & 58.5385 \\
\hline FREIBAUER A, 2004, GEODERMA & 10.1016/j.geoderma.2004.01.021 & 599 & 33.2778 \\
\hline KLEIJN D, 2001, NATURE & $10.1038 / 35099540$ & 489 & 23.2857 \\
\hline $\begin{array}{c}\text { PANAGOS P, 2015, ENVIRON SCI } \\
\text { POLICY }\end{array}$ & 10.1016/j.envsci.2015.08.012 & 472 & 67.4286 \\
\hline $\begin{array}{c}\text { FAAIJ APC, 2006, ENERGY } \\
\text { POLICY }\end{array}$ & 10.1016/j.enpol.2004.03.026 & 377 & 23.5625 \\
\hline BATARY P, 2015, CONSERV BIOL & 10.1111/cobi.12536 & 366 & 52.2857 \\
\hline $\begin{array}{c}\text { STRIJKER D, 2005, BASIC APPL } \\
\text { ECOL }\end{array}$ & 10.1016/j.baae.2005.01.001 & 281 & 16.5294 \\
\hline $\begin{array}{c}\text { PANAGOS P, 2015, LAND USE } \\
\text { POLICY }\end{array}$ & 10.1016/j.landusepol.2015.05.021 & 270 & 38.5714 \\
\hline $\begin{array}{c}\text { SRBINOVSKA M, 2015, J CLEAN } \\
\text { PROD }\end{array}$ & 10.1016/j.jclepro.2014.04.036 & 264 & 37.7143 \\
\hline LUO Z, 2010, GEODERMA & 10.1016/j.geoderma.2009.12.012 & 238 & 19.8333 \\
\hline FISCHER J, 2012, CONSERV LETT & 10.1111/j.1755-263X.2012.00227.x & 232 & 23.2 \\
\hline $\begin{array}{l}\text { DARNHOFER I, 2010, AGRON } \\
\text { SUSTAINABLE DEV }\end{array}$ & 10.1051 /agro/2009053 & 213 & 17.75 \\
\hline $\begin{array}{c}\text { DONALD PF, 2002, AGRIC } \\
\text { ECOSYST ENVIRON }\end{array}$ & 10.1016/S0167-8809(01)00244-4 & 208 & 10.4 \\
\hline $\begin{array}{c}\text { CONCEPCIN ED, 2008, LANDSC } \\
\text { ECOL }\end{array}$ & $10.1007 / \mathrm{s} 10980-007-9150-2$ & 206 & 14.7143 \\
\hline $\begin{array}{c}\text { POTTER C, 2005, PROG HUM } \\
\text { GEOGR }\end{array}$ & 10.1191/0309132505ph569oa & 205 & 12.0588 \\
\hline $\begin{array}{c}\text { PICAZO-TADEO AJ, 2011, J } \\
\text { ENVIRON MANAGE }\end{array}$ & 10.1016/j.jenvman.2010.11.025 & 199 & 18.0909 \\
\hline $\begin{array}{c}\text { KRAUSMANN F, 2003, LAND USE } \\
\text { POLICY }\end{array}$ & 10.1016/S0264-8377(02)00048-0 & 181 & 9.5263 \\
\hline $\begin{array}{l}\text { WHITTINGHAM MJ, 2007, J APPL } \\
\text { ECOL }\end{array}$ & 10.1111/j.1365-2664.2006.01263.x & 178 & 11.8667 \\
\hline
\end{tabular}


Table 3. Documents present in the sample most cited by others in the sample.

\begin{tabular}{|c|c|c|c|c|c|}
\hline Document & DOI & Year & $\begin{array}{l}\text { Local } \\
\text { Citations }\end{array}$ & $\begin{array}{l}\text { Global } \\
\text { Citations }\end{array}$ & $\begin{array}{l}\text { Local Citations } \\
\text { (\%) }\end{array}$ \\
\hline $\begin{array}{c}\text { BATRY P, 2015, CONSERV } \\
\text { BIOL }\end{array}$ & 10.1111/cobi.12536 & 2015 & 41 & 366 & 11.20 \\
\hline $\begin{array}{l}\text { LOWE P, 2002, J RURAL } \\
\text { STUD }\end{array}$ & $\begin{array}{l}\text { 10.1016/S0743- } \\
0167(01) 00025-0\end{array}$ & 2002 & 34 & 175 & 19.43 \\
\hline $\begin{array}{c}\text { RIZOV M, 2013, J AGRIC } \\
\text { ECON }\end{array}$ & $10.1111 / 1477-9552.12030$ & 2013 & 31 & 95 & 32.63 \\
\hline $\begin{array}{c}\text { TRANTER RB, 2007, FOOD } \\
\text { POLICY }\end{array}$ & 10.1016/j.foodpol.2007.04.001 & 2007 & 30 & 58 & 51.72 \\
\hline $\begin{array}{l}\text { BRADY M, 2009, J AGRIC } \\
\text { ECON }\end{array}$ & $\begin{array}{c}\text { 10.1111/j.1477- } \\
9552.2009 .00216 . x\end{array}$ & 2009 & 28 & 85 & 32.94 \\
\hline $\begin{array}{c}\text { MATTHEWS A, 2013, } \\
\text { BIO-BASED APPL } \\
\text { ECONOMICS }\end{array}$ & & 2013 & 27 & 83 & 32.53 \\
\hline $\begin{array}{c}\text { STOATE C, 2001, J ENVIRON } \\
\text { MANAGE }\end{array}$ & 10.1006/jema.2001.0473 & 2001 & 26 & 818 & 3.18 \\
\hline ZHU X, 2010, J AGRIC ECON & $\begin{array}{l}\text { 10.1111/j.1477- } \\
\text { 9552.2010.00254.x }\end{array}$ & 2010 & 25 & 97 & 25.77 \\
\hline $\begin{array}{c}\text { STOATE C, 2009, J ENVIRON } \\
\text { MANAGE }\end{array}$ & 10.1016/j.jenvman.2009.07.005 & 2009 & 23 & 761 & 3.02 \\
\hline $\begin{array}{c}\text { POTTER C, 2005, PROG HUM } \\
\text { GEOGR }\end{array}$ & 10.1191/0309132505ph569oa & 2005 & 23 & 205 & 11.22 \\
\hline $\begin{array}{c}\text { PIORR A, 2009, ENVIRON } \\
\text { SCI POLICY }\end{array}$ & 10.1016/j.envsci.2009.01.001 & 2009 & 22 & 79 & 27.85 \\
\hline $\begin{array}{c}\text { GOCHT A, 2017, J AGRIC } \\
\text { ECON }\end{array}$ & $10.1111 / 1477-9552.12217$ & 2017 & 21 & 38 & 55.26 \\
\hline $\begin{array}{l}\text { BARTOLINI F, 2013, LAND } \\
\text { USE POLICY }\end{array}$ & 10.1016/j.landusepol.2011.10.007 & 2013 & 20 & 67 & 29.85 \\
\hline $\begin{array}{c}\text { GOHIN A, 2006, J AGRIC } \\
\text { ECON }\end{array}$ & $\begin{array}{l}\text { 10.1111/j.1477- } \\
\text { 9552.2006.00058.x }\end{array}$ & 2006 & 20 & 46 & 43.48 \\
\hline $\begin{array}{l}\text { PE'ER G, 2017, CONSERV } \\
\text { LETT }\end{array}$ & 10.1111/conl.12333 & 2017 & 19 & 90 & 21.11 \\
\hline $\begin{array}{l}\text { GORTON M, 2009, REG } \\
\text { STUD }\end{array}$ & $10.1080 / 00343400802508802$ & 2009 & 19 & 74 & 25.68 \\
\hline $\begin{array}{l}\text { DONALD PF, 2002, AGRIC } \\
\text { ECOSYST ENVIRON }\end{array}$ & $\begin{array}{l}\text { 10.1016/S0167- } \\
8809(01) 00244-4\end{array}$ & 2002 & 19 & 208 & 9.13 \\
\hline KLEIJN D, 2001, NATURE & $10.1038 / 35099540$ & 2001 & 19 & 489 & 3.89 \\
\hline $\begin{array}{c}\text { FISCHER J, 2012, CONSERV } \\
\text { LETT }\end{array}$ & $\begin{array}{c}\text { 10.1111/j.1755- } \\
\text { 263X.2012.00227.x }\end{array}$ & 2012 & 18 & 232 & 7.76 \\
\hline $\begin{array}{l}\text { LOBLEY M, 2010, FOOD } \\
\text { POLICY }\end{array}$ & 10.1016/j.foodpol.2010.04.001 & 2010 & 17 & 38 & 44.74 \\
\hline
\end{tabular}

Table 2 represents the most cited paper in the sample; this tables provides some information in two levels, both in absolute terms and in relative terms (weighting the citation number by the number of years). For this reason, we have two indicators, Total Citation and Tc per Year (total citation per year).

The most cited papers in the sample in absolute terms are:

- Olesen and Bindi (2002), with 863 citations. In their paper, they pointed out the consequences of climate change on European agricultural productivity and the role of agricultural policy in supporting the mitigation and adaptation of European agriculture against climate change [29];

- Stoate et al. (2001), with 818 citations, analyzed the ecological impact of arable land and the necessity to implement the EU Rural Development Regulation [30];

- Stoate et al. (2009), with 761 citations, provided an overview of the ecological status of agricultural systems across the European Union in light of recent policy changes [31]. 
For the second indicator, TC per year, the three most important papers with over 50 citations on average are:

- Panagos et al. (2015) investigated the effects of soil erosion on Europe's agricultural productivity, thanks to the application of a modified version of the Revised Universal Soil Loss Equation (RUSLE) model (RUSLE2015), and evaluated the impacts of policy interventions (CAPs) [32];

- Stoate et al. (2009) have an index of Total Citation per Year of around 58.5\%;

- Batàry et al. (2015) evaluated the effects of Agri-environmental schemes (AES) on species and ecosystem conservation in Europe. This is a very important study because AES represent a major source of nature conservation funding within the European Union [33].

Table 3 shows which documents were cited several times by the others articles in the sample.

Below, we identify the most connected references, which can be considered the main theoretical pillars of the field.

- $\quad$ Tranter et al. (2007). Food Policy, 32(5-6), 656-671.

In their paper, they evaluate among three European countries (Germany, Portugal, and UK) the effects of decoupled income support for farmers, called Single Farm Payment (SFP), introduced by the CAP 2003 reform [34];

- $\quad$ Gocht et al. (2017). Journal of Agricultural Economics, 68(3), 651-681.

In this paper, the authors investigate the economic and environmental impacts of CAP greening introduced by the 2013 CAP reform using the CAPRI model. The findings show that both the economic (land use, production, price, and income) and environmental impacts are very small [35];

- $\quad$ Rizov et al. (2013). Journal of Agricultural Economics, 64(3), 537-557.

The purpose of this paper was to investigate the effects of the subsidies introduced by the Common Agricultural Policy on on-farm productivity in the European Union [36].

Briefly, Table 3 analyzes the documents via two different co-citation analyses, denoting a comparative approach that constitutes the basis of our study. The findings show how the different approaches provide quite different results, confirming the usefulness of a comparative approach to bibliometrics when identifying studies of influence.

\subsection{Keyword Analysis}

When analyzing the content of the articles, the analysis of the co-occurrence of keywords is very useful, according to Fakhar Manesh et al. This analysis is based on the idea that a research specialty can be identified by the particular associations established between its keywords. This analysis provides us the thematic areas/clusters that make up the theoretical building blocks or foundational topics for the field under inquiry [37].

From the results of the keyword analysis (Figure 6), it is possible to obtain three groups, i.e., Political Economy (green cluster), Agricultural Planning (red cluster) and Biodiversity (blue cluster). These finding are very important because they are representative of the new formulation of CAP 2021-2027, where, in addition to the economic aspect of supporting the farmers, more objectives linked to environmental sustainability and rural development have been introduced, showing that the scientific community made a very important contribution in the construction of the new formulation [24,38,39].

Another useful approach is to use overlay visualization. Figure 7 represents the temporal distribution of the keywords in each cluster. The novelty of this approach is that, in the diagram, the keywords are colored according to a score, which is assigned based on the average years of occurrence of each keyword, allowing us to capture the temporal evolution of a phenomenon and the issues dealt with within the scientific community. The range of colors varies from blue to green to yellow, where blue indicates older years, while green and in particular yellow refer to more recent years. 


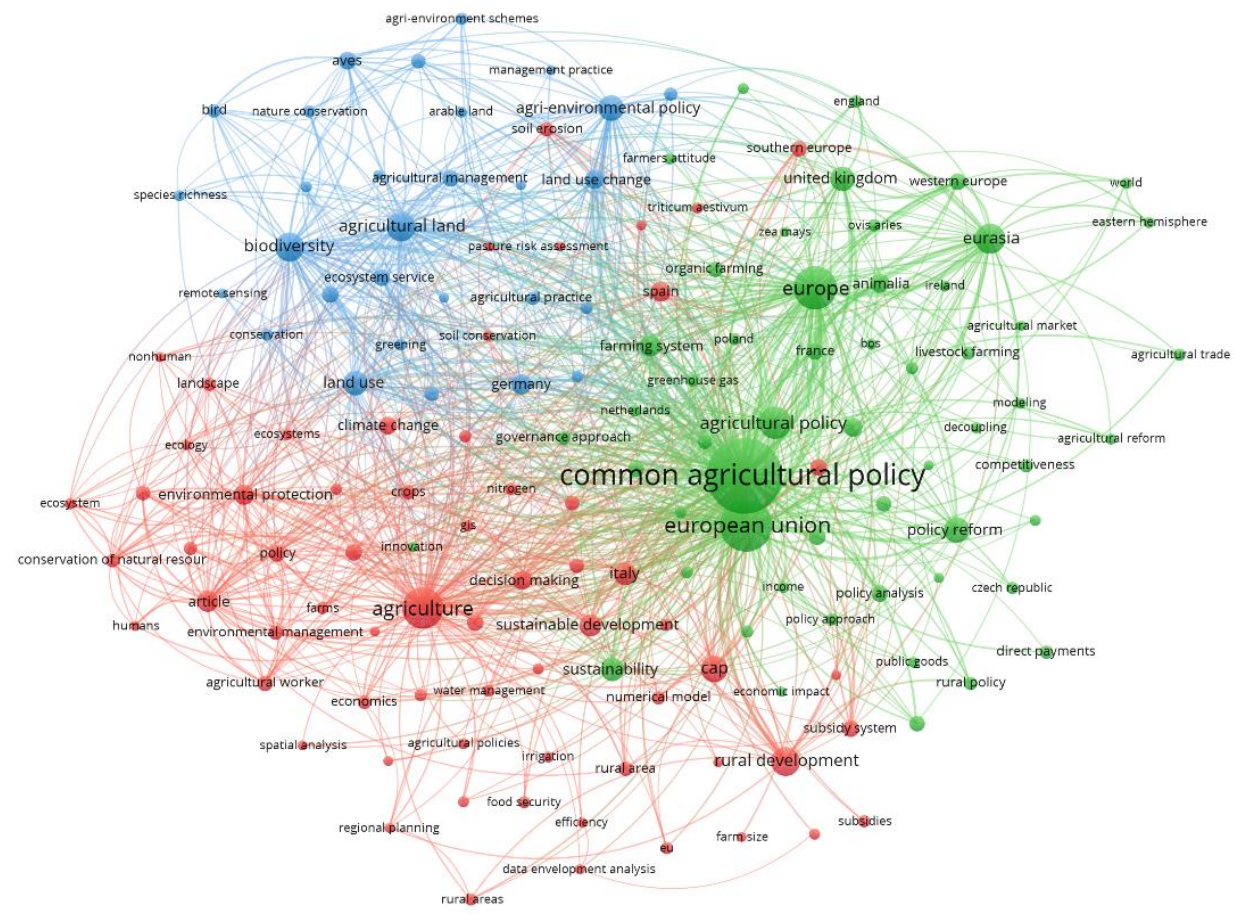

A vosviewer

Figure 6. Network diagram of the co-occurrence of keywords. Source: own elaboration.

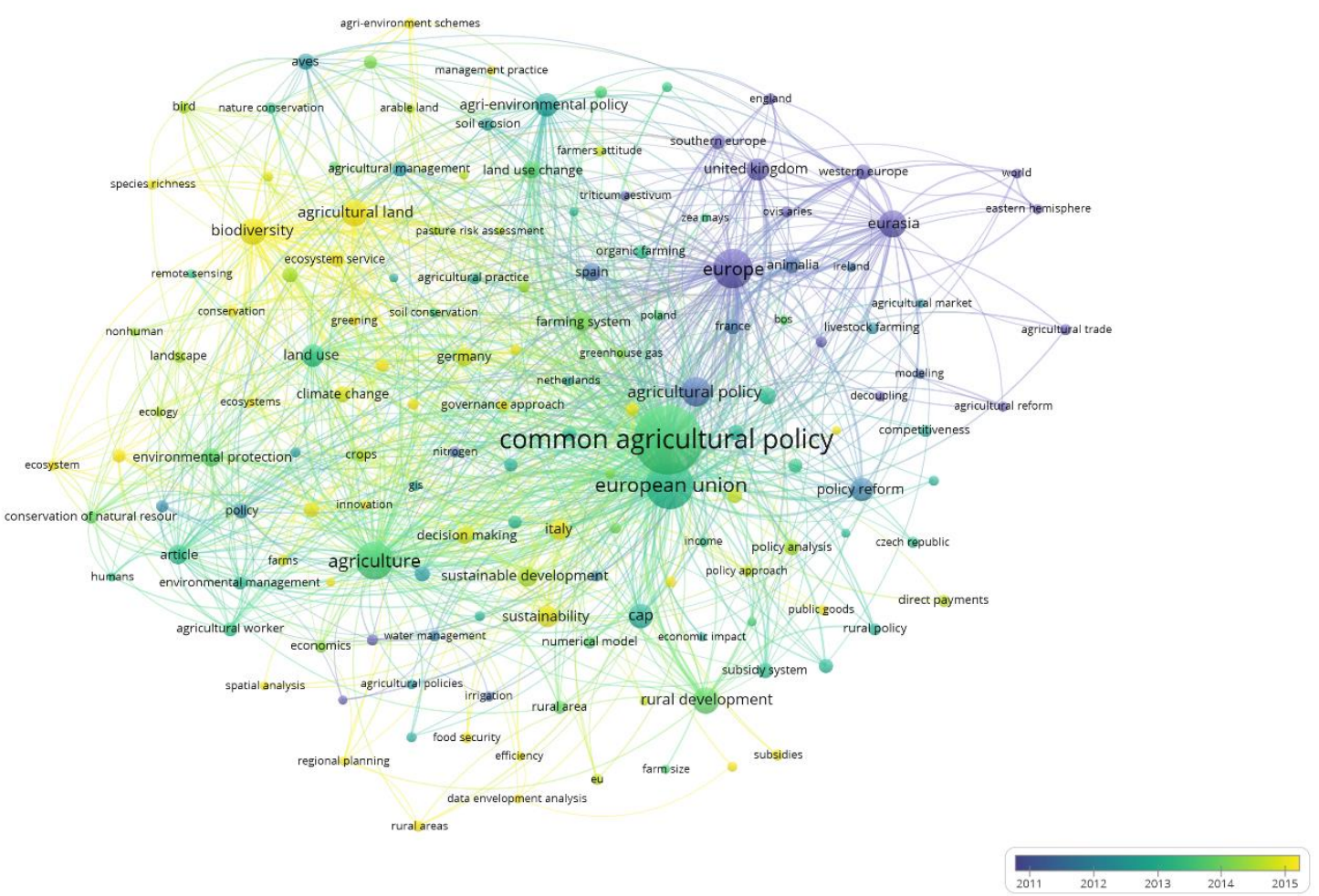

Figure 7. Overlay diagram of the co-occurrence of keywords. Source: own elaboration. 
The analysis highlights the evolutionary pathway of CAP during the last twenty years. In particular, the emerging themes concern biodiversity and sustainability, and the issues related to the policies of specific nations have now been adopted by a more systemic approach than community policies.

\section{Discussions}

The bibliometric analysis represents a methodological approach widely used by academics to analyze the state-of-the-art of a specific field of studies. However, bridging the gap between theory and practice requires the adoption of a scientific and systematic approach inspired by the need to extract insights from the analysis. In this sense, we have identified a set of implications related to each of the three clusters identified in the study.

\subsection{Green Cluster: Political Economy}

In the last twenty years, the European Commission has invested many financial resources to sustain the CAP. In this sense, the specific focus of academics on the political dimension of the CAP represents a direct consequence of the European scenario. In particular, the two main research lines can be synthesized in the form of regional studies and financial dynamics. The regional studies analyze the impacts related to the introduction of agricultural policies in different contexts, such as the south [29,40], the east [21], the west [2,34], and the north of Europe [31,41]. Furthermore, other studies were conducted to identify the effects related to the implementation of reforms $[25,28]$. The studies on financial dynamics cover different topics. In particular, the bibliometric analysis reveals the existence of research about financial risks [42], subsidies [23] and economic dimensions [21]. Furthermore, other studies have identified the main constraints and opportunities related to the investments made by the European Commission to support entrepreneurs and farmers $[24,36]$

\subsection{Red Cluster: Agricultural Planning}

The concept of agricultural planning covers different topics, such as the geographical and economical dynamics of rural areas. In fact, the need to consider critical issues such as climate change and food security in public policies has been followed by several initiatives to mitigate negative externalities $[3,43]$. Furthermore, many studies are focused on the rural development and requalification of these particular areas [22,44,45].

\subsection{Blue Cluster: Biodiversity}

The third cluster (blue) addresses the concept of biodiversity. The blue cluster is directly related to the CAP's aims. In fact, one of the latest reports published by the European Commission stated: "Farmers have a double challenge — to produce food whilst simultaneously protecting nature and safeguarding biodiversity. Using natural resources prudently is essential for our food production and for our quality of life-today, tomorrow and for future generations", [5]. Thus, this represents a critical research area for academics interested in actively contributing to policymaking.

In these years, this topic has played an important role due to the increasing intensification of agriculture, which has generated losses of semi-natural habitats and crop diversity [46-48]. In this scenario, the interest of academics is focusing on whether or not CAP reforms really facilitate increases in biodiversity $[49,50]$. The results in this direction are very confused, because some researchers state that, due to the voluntary adoption of the second pillar-in particular, farmers tend to adopt this type of measure with simple management actions, with limited results in terms of biodiversity-the spread of more complex actions is very limited [51,52]. To address these limitations, many studies have been conducted in order to assess the relationship between biodiversity and CAP, in order to provide some information that will assist the implementation of CAP 2021-2027, because the effects of the CAP reforms on biodiversity could be different depending on the complexity of the farm enterprise [27], the countries where the agricultural holdings are 
located $[53,54]$, the landscape characteristic of the country $[55,56]$, and the compatibility of direct payment schemes $[57,58]$.

\section{Concluding Remarks}

In the last few years, there have been many investments made by the European Commission to sustain the development of the agricultural sector, which represents a critical sector within the European context. Academics have underlined the relevance of these initiatives, as evidenced by the increasing number of scientific papers published in the last few years. In fact, public investments are usually considered as strategic drivers for the development of a more effective agricultural sector.

This paper aims to systematize the scientific knowledge about CAP through bibliometric indicators. Despite the increasing involvement of academics in policymaking, the future of an economic system based on continuous engagement between academics, policymakers and practitioners remains characterized by many cultural barriers. In this sense, bridging the gap between scientific and managerial knowledge represents a critical challenge for academics interested in actively contributing to the development of political tools useful to support farmers and agricultural organizations. In this sense, the main aim of the study consists of, firstly, the attempt to systematize a scientific debate characterized by different point of view. In fact, contrarily to other research areas, the scientific debate about CAP is influenced also by the involvement of academics with different scientific backgrounds, such as economists, jurists and biologists.

Building on this evidence, the analysis reveals the opportunity for European policymakers to involve academics in their decision-making processes. The coexistence of different research areas underlines the opportunity to identify new evolutionary pathways through the main insights collected by academics through their evidence-based approaches. In this sense, the knowledge transfer between academics, policymakers and practitioners could represent a strategic driver for development in the agricultural sector.

The attempt to systematize the scientific debate on CAP through bibliometric indicators could be supported by the development of new studies based on alternative methods. In fact, bibliometric analysis is subject to some criticisms related to the adoption of digital tools. In this sense, future research could combine bibliometric analysis with qualitative reflections based on methods such as systematic literature reviews and Latent Dirichlet Allocation (LDA).

Funding: This research received no external funding.

Data Availability Statement: The data are available on request.

Conflicts of Interest: The author declares no conflict of interest.

\section{References}

1. Petrescu-Mag, R.-M.; Creanga, S.; Petrescu, D.-C.; Petrescu U-Mag, I.-V. Sustainable rural development in the context of common agricultural policy beyond 2013. Qual. Access Success 2011, 447-453.

2. Pardo, A.; Rolo, V.; Concepción, E.D.; Díaz, M.; Kazakova, Y.; Stefanova, V.; Marsden, K.; Brandt, K.; Jay, M.; Piskol, S.; et al. To what extent does the European common agricultural policy affect key landscape determinants of biodiversity? Environ. Sci. Policy 2020. [CrossRef]

3. Syp, A.; Osuch, D. Assessing greenhouse gas emissions from conventional farms based on the farm accountancy data network. Polish J. Environ. Stud. 2018. [CrossRef]

4. Hodge, I.; Hauck, J.; Bonn, A. The alignment of agricultural and nature conservation policies in the European Union. Conserv. Biol. 2015. [CrossRef] [PubMed]

5. European Commission. The Common Agricultural Policy at a Glance. Available online: https://ec.europa.eu/info/food-farmingfisheries/key-policies/common-agricultural-policy/cap-glance_en (accessed on 21 September 2021).

6. De Castro, P.; Adinolfi, F.; Capitanio, F. Family farming issues and challenges in the reformed common agricultural policy. Econ Agrar. y Recur. Nat. 2014. [CrossRef]

7. De Castro, P.; Miglietta, P.P.; Vecchio, Y. The Common Agricultural Policy 2021-2027: A new history for European agriculture. Ital. Rev. Agric. Econ. 2020, 75, 5-12. [CrossRef] 
8. Ferreira, F.A.F. Mapping the field of arts-based management: Bibliographic coupling and co-citation analyses. J. Bus. Res. 2018, 85, 348-357. [CrossRef]

9. Marzi, G.; Dabić, M.; Daim, T.; Garces, E. Product and process innovation in manufacturing firms: A 30-year bibliometric analysis. Scientometrics 2017, 113, 673-704. [CrossRef]

10. Zupic, I.; Čater, T. Bibliometric Methods in Management and Organization. Organ. Res. Methods 2015, 18, 429-472. [CrossRef]

11. Sharma, G.; Bansal, P. Partnering Up: Including Managers as Research Partners in Systematic Reviews. Organ. Res. Methods 2020, 109442812096570. [CrossRef]

12. Deboe, G. Impacts of agricultural policies on productivity and sustainability performance in agriculture: A literature review. OECD Food Agric. Fish. Pap. 2020, 1-78. [CrossRef]

13. Fitz-Koch, S.; Nordqvist, M.; Carter, S.; Hunter, E. Entrepreneurship in the agricultural sector: A literature review and future research opportunities. Entrep. Theory Pract. 2018, 42, 129-166. [CrossRef]

14. Andersson, J.A.; D'Souza, S. From adoption claims to understanding farmers and contexts: A literature review of Conservation Agriculture (CA) adoption among smallholder farmers in southern Africa. Agric. Ecosyst. Environ. 2014, 187, 116-132. [CrossRef]

15. Van Eck, N.J.; Waltman, L. Software survey: VOSviewer, a computer program for bibliometric mapping. Scientometrics 2010, 84 523-538. [CrossRef]

16. Aria, M.; Cuccurullo, C. bibliometrix: An R-tool for comprehensive science mapping analysis. J. Informetr. 2017, 11, 959-975. [CrossRef]

17. Rodríguez-Soler, R.; Uribe-Toril, J.; De Pablo Valenciano, J. Worldwide trends in the scientific production on rural depopulation, a bibliometric analysis using bibliometrix R-tool. Land Use Policy 2020, 97, 104787. [CrossRef]

18. Bartolacci, F.; Caputo, A.; Fradeani, A.; Soverchia, M. Twenty Years of XBRL: What We Know and Where We Are Going. Meditari Account. Res. 2020. [CrossRef]

19. Batistič, S.; van der Laken, P. History, Evolution and Future of Big Data and Analytics: A Bibliometric Analysis of Its Relationship to Performance in Organizations. Br. J. Manag. 2019, 30, 229-251. [CrossRef]

20. Mao, G.; Huang, N.; Chen, L.; Wang, H. Research on biomass energy and environment from the past to the future: A bibliometric analysis. Sci. Total Environ. 2018, 635, 1081-1090. [CrossRef] [PubMed]

21. Martino, S.; Muenzel, D. The economic value of high nature value farming and the importance of the Common Agricultural Policy in sustaining income: The case study of the Natura 2000 Zarandul de Est (Romania). J. Rural Stud. 2018. [CrossRef]

22. Jaime, M.M.; Coria, J.; Liu, X. Interactions between CAP Agricultural and Agri-Environmental Subsidies and Their Effects on the Uptake of Organic Farming. Am. J. Agric. Econ. 2016. [CrossRef]

23. Baculáková, K.; Harakal'ová, L'. Allocation of financial resources from EARDF in the context of typology of Slovak regions. J. Environ. Manag. Tour. 2018. [CrossRef]

24. Coluccia, B.; Valente, D.; Fusco, G.; De Leo, F.; Porrini, D. Assessing agricultural eco-efficiency in Italian Regions. Ecol. Indic. 2020, 116, 106483. [CrossRef]

25. Scown, M.W.; Nicholas, K.A. European agricultural policy requires a stronger performance framework to achieve the Sustainable Development Goals. Glob. Sustain. 2020. [CrossRef]

26. Severini, S.; Di Tommaso, G.; Finger, R. Effects of the Income Stabilization Tool on farm income level, variability and concentration in Italian agriculture. Agric. Food Econ. 2019. [CrossRef]

27. Larkin, J.; Sheridan, H.; Finn, J.A.; Denniston, H.; Ó hUallacháin, D. Semi-natural habitats and Ecological Focus Areas on cereal, beef and dairy farms in Ireland. Land Use Policy 2019. [CrossRef]

28. Scown, M.W.; Brady, M.V.; Nicholas, K.A. Billions in Misspent EU Agricultural Subsidies Could Support the Sustainable Development Goals. One Earth 2020. [CrossRef]

29. Olesen, J.E.; Bindi, M. Consequences of climate change for European agricultural productivity, land use and policy. Eur. J. Agron. 2002. [CrossRef]

30. Stoate, C.; Boatman, N.D.; Borralho, R.J.; Carvalho, C.R.; De Snoo, G.R.; Eden, P. Ecological impacts of arable intensification in Europe. J. Environ. Manag. 2001. [CrossRef]

31. Stoate, C.; Báldi, A.; Beja, P.; Boatman, N.D.; Herzon, I.; van Doorn, A.; de Snoo, G.R.; Rakosy, L.; Ramwell, C. Ecological impacts of early 21st century agricultural change in Europe-A review. J. Environ. Manag. 2009. [CrossRef] [PubMed]

32. Panagos, P.; Borrelli, P.; Poesen, J.; Ballabio, C.; Lugato, E.; Meusburger, K.; Montanarella, L.; Alewell, C. The new assessment of soil loss by water erosion in Europe. Environ. Sci. Policy 2015. [CrossRef]

33. Batáry, P.; Dicks, L.V.; Kleijn, D.; Sutherland, W.J. The role of agri-environment schemes in conservation and environmental management. Conserv. Biol. 2015. [CrossRef] [PubMed]

34. Tranter, R.B.; Swinbank, A.; Wooldridge, M.J.; Costa, L.; Knapp, T.; Little, G.P.J.; Sottomayor, M.L. Implications for food production, land use and rural development of the European Union's Single Farm Payment: Indications from a survey of farmers' intentions in Germany, Portugal and the UK. Food Policy 2007. [CrossRef]

35. Gocht, A.; Ciaian, P.; Bielza, M.; Terres, J.-M.; Röder, N.; Himics, M.; Salputra, G. EU-wide Economic and Environmental Impacts of CAP Greening with High Spatial and Farm-type Detail. J. Agric. Econ. 2017. [CrossRef]

36. Rizov, M.; Pokrivcak, J.; Ciaian, P. CAP subsidies and productivity of the EU farms. J. Agric. Econ. 2013. [CrossRef]

37. Fakhar Manesh, M.; Pellegrini, M.M.; Marzi, G.; Dabic, M. Knowledge Management in the Fourth Industrial Revolution: Mapping the Literature and Scoping Future Avenues. IEEE Trans. Eng. Manag. 2021, 68, 289-300. [CrossRef] 
38. Viaggi, D. Bioeconomy and the common agricultural policy: Will a strategy in search of policies meet a policy in search of strategies? Bio-Based Appl. Econ. 2018. [CrossRef]

39. Schulte, R.P.O.; O'Sullivan, L.; Vrebos, D.; Bampa, F.; Jones, A.; Staes, J. Demands on land: Mapping competing societal expectations for the functionality of agricultural soils in Europe. Environ. Sci. Policy 2019. [CrossRef]

40. Giaccio, V.; Giannelli, A.; Mastronardi, L. Explaining determinants of Agri-tourism income: Evidence from Italy. Tour. Rev. 2018, 73, 216-229. [CrossRef]

41. Jeanneaux, P.; Capitaine, M.; Mauclair, A. PerfCuma: A framework to manage the sustainable development of small cooperatives. Int. J. Agric. Manag. 2018, 7, 68-79. [CrossRef]

42. Capitanio, F.; De Pin, A. Measures of Efficiency of Agricultural Insurance in Italy, Economic Evaluations. Risks 2018, 6, 126. [CrossRef]

43. Partey, S.T.; Zougmoré, R.B.; Ouédraogo, M.; Campbell, B.M. Developing climate-smart agriculture to face climate variability in West Africa: Challenges and lessons learnt. J. Clean. Prod. 2018, 187, 285-295. [CrossRef]

44. Canali, G. Common agricultural policy reform and its effects on sheep and goat market and rare breeds conservation. Small Rumin. Res. 2006. [CrossRef]

45. Vavřina, J.; Martinovičová, D. Economic performance of SME agricultural producers in the context of risk management: Focus on Visegrad 4 member countries. Acta Univ. Agric. Silvic. Mendel. Brun. 2014. [CrossRef]

46. Donald, P.F.; Pisano, G.; Rayment, M.D.; Pain, D.J. The common agricultural policy, EU enlargement and the conservation of Europe's farmland birds. Agric. Ecosyst. Environ. 2002. [CrossRef]

47. Berendse, F.; Chamberlain, D.; Kleijn, D.; Schekkerman, H. Declining biodiversity in agricultural lanscapes and the effectiveness of agri-environment schemes. Ambio 2004. [CrossRef] [PubMed]

48. Brodzińska, K. Problems of Biodiversity Conservation in Polish Agriculture. Agroecol. Sustain. Food Syst. 2015. [CrossRef]

49. Lefebvre, M.; Midler, E.; Bontems, P. Adoption of Environment-Friendly Agricultural Practices with Background Risk: Experimental Evidence. Environ. Resour. Econ. 2020. [CrossRef]

50. Leventon, J.; Schaal, T.; Velten, S.; Dänhardt, J.; Fischer, J.; Abson, D.J.; Newig, J. Collaboration or fragmentation? Biodiversity management through the common agricultural policy. Land Use Policy 2017. [CrossRef]

51. Ingram, J.; Morris, C. The knowledge challenge within the transition towards sustainable soil management: An analysis of agricultural advisors in England. Land Use Policy 2007. [CrossRef]

52. Hanley, N.; Acs, S.; Dallimer, M.; Gaston, K.J.; Graves, A.; Morris, J.; Armsworth, P.R. Farm-scale ecological and economic impacts of agricultural change in the uplands. Land Use Policy 2012. [CrossRef]

53. Sutcliffe, L.M.E.; Batáry, P.; Kormann, U.; Báldi, A.; Dicks, L.V.; Herzon, I.; Kleijn, D.; Tryjanowski, P.; Apostolova, I.; Arlettaz, R.; et al. Harnessing the biodiversity value of Central and Eastern European farmland. Divers. Distrib. 2015. [CrossRef]

54. Overmars, K.P.; Helming, J.; van Zeijts, H.; Jansson, T.; Terluin, I. A modelling approach for the assessment of the effects of Common Agricultural Policy measures on farmland biodiversity in the EU27. J. Environ. Manag. 2013. [CrossRef] [PubMed]

55. Cormont, A.; Siepel, H.; Clement, J.; Melman, T.C.P.; WallisDeVries, M.F.; van Turnhout, C.A.M.; Sparrius, L.B.; Reemer, M.; Biesmeijer, J.C.; Berendse, F.; et al. Landscape complexity and farmland biodiversity: Evaluating the CAP target on natural elements. J. Nat. Conserv. 2016. [CrossRef]

56. Morelli, F. High nature value farmland increases taxonomic diversity, functional richness and evolutionary uniqueness of bird communities. Ecol. Indic. 2018. [CrossRef]

57. Hristov, J.; Clough, Y.; Sahlin, U.; Smith, H.G.; Stjernman, M.; Olsson, O.; Sahrbacher, A.; Brady, M.V. Impacts of the EU's Common Agricultural Policy "Greening" Reform on Agricultural Development, Biodiversity, and Ecosystem Services. Appl. Econ. Perspect. Policy 2020. [CrossRef]

58. Nilsson, L.; Clough, Y.; Smith, H.G.; Alkan Olsson, J.; Brady, M.V.; Hristov, J.; Olsson, P.; Skantze, K.; Ståhlberg, D.; Dänhardt, J. A suboptimal array of options erodes the value of CAP ecological focus areas. Land Use Policy 2019. [CrossRef] 